\title{
MULTILITERATION LEARNING IN WRITING ENGLISH DESCRIPTIVE TEXT THROUGH COLLABORATIVE TECHNIQUES - (THEORITICAL REVIEW)
}

\section{Santi Mayasari, Masagus Firdaus, Tri Widayatsih}

University of PGRI Palembang

santimayasarisei@gmail.com

\section{Article History}

accepted 09/07/2018

approved 01/08/2018

published 17/09/2018

\section{Keywords}

Multiliteration learning, collaborative, creative

\begin{abstract}
MultiliterationLearningthrough collaborative techniques is one of the studyused by teachers and lecturers in disruption era. Disruption era is an era that needs a very rapid change and transforming old things into new and work intensein the world competition, and the movement of the highly developed world industry makes us as teachers or lecturers to be ready to prepare our students in this sophisticated era. Teachers are required to be more creative in delivering classroom learning. Multiliteration learning through collaborative techniques becomes one of the more creative learning alternatives. Multiliterationlearningis used to develop the competence of various sources of literacy bothvisual literacy, multimedia, technology, critical, cross curriculum, as well as various literacy resources that exist around people's lives. In Modern learning using a more attractive and sophisticated facilities that are able to explore the potential and mindset of learners to be more qualified. The teacher will dig the students creative and fun. The benefits of multiliterationlearning in Teaching English are; (1) to explore more creative ideasin English descriptivetext, (2) to improve the studentsEnglish grammar; (3) to master the vocabulary in a descriptive text; and (4) to use the best facilities at school to support the development of multiliterationstudy.
\end{abstract}

Social, Humanities, and Education Studies (SHEs): Conference Series https://jurnal.uns.ac.id/shes
p-ISSN 2620-9284

e-ISSN 2620-9292 


\section{PENDAHULUAN}

\subsection{Latar Belakang}

Menulis merupakan keterampilan yang sangat diperlukan dalam pembelajaran Bahasa Inggris disamping mendengar, membaca dan berbicara. Keterampilan menulis memberikan kesempatan kepada peserta didik untuk mengembangkan ide-ide yang kreatif yang mereka miliki dalam sebuah karya tulis. Dengan keterampilan menulis peserta didik mampu menggali potensi lain yang mereka miliki. Dizaman yang canggih seperti sekarang ini tak jarang peserta didik kita menuangkan kemampuan tulisan mereka di sosial media yang nantinya bisa dibaca oleh masyarakat banyak. Update status atau pun upload foto-foto dengan caption dibawah foto merupakan hasil dari ideide dan kreatifitas mereka. Bahkan tak jarang mereka memiliki keterbatasan pemikiran dan keterbatasan ide-ide yang kuarang baik dan tidak memiliki etika menulis yang baik yang terlanjur mereka post di sosial media.

Ide-ide yang kurang berkembang sudah sepatutnya menjadi salah tanggung jawab guru dan dosen untuk menemukan teknik dan metode yang tepat dalam menggali ide-ide serta penggabungan aspek-aspek yang belum muncul untuk dijadiakan sebuah karya tulis yang indah dan beretika. Proses pembelajaran yang lebih kreatif diharapkan mampu untuk mengatasi masalah ini. Guru dan dosen diharapkan memiliki ide-ide kreatif untuk menciptakan teknik, metode serta pendekatan yang lebih modern dalam pengajaran khususnya pengajaran Bahasa Inggris. Pengajaran Bahasa Inggris dipandang perlu memiliki inovasi pengajaran yang lebih maju mengingat perkembangan dunia yang semakin canggih dan modern di Abad XX1 ini.

Sistem pembelajaran abad XX1 merupakan suatu proses transisi dimana kurikulum yang dikembangkan menuntut sekolah untuk merubah pendekatan pembelajaran yang terpusat pada guru (teacher centered) menjadi berpusat pada peserta didik (student centered). Hal ini dapat dimaknai bahwa didalam kegiatan pembelajaran, peserta didik harus secara aktif terlibat dan pada akhirnya mereka akan mampu menemukan pengalaman belajar yang sesuai dengan apa yang mereka butuhkan dalam kehidupan nyata.

Gagasan diatas sejalan dengan apa yang telah dinyatakan oleh Abidin (2014:2). Beliau mengemukakan bahwa pembelajaran merupakan suatu proses yang melibatkan mental peserta didik yang menghendaki aktifitas mereka untuk berfikir kritis dan berfikir kreatif. Proses pembelajaran idealnya perlu mengedepankan konsep yang bertujuan untuk memperbaiki dan meningkatkan kemampuan berfikir peserta didik yang pada saatnya nanti akan mampu membantu peserta didik untuk memperoleh pengetahuan lebih optimal. Lebih jauh beliau mengatakan bahwa dalam kaitannya dengan pembelajaran multiliterasi terdapat hubungan antara materi yang dipelajari dengan apa yang telah diketahui oleh peserta didik (prior knowledge). Hal ini dimungkinkan karena ketika materi pembelajaran berkenaan dengan pengetahuan terdahulu oleh peserta didik, proses pemahaman akan menjadi lebih mudah. Peserta didik akan mampu menghubungkan pengetahuan mereka dengan materi yang dipelajari sehingga terbentuk pemahaman yang lebih baik pada diri peserta didik. Pembelajaran multiliterasi menghubungkan materi yang dipelajari dengan kehidupan nyata dan isu-isu kontemporer. Hal ini karena isu-isu kontemporer dapat dengan mudah diperoleh peserta didik dan dijadikan tambahan gagasan bagi mereka.

Pembelajaran multiliterasi melibatkan peserta didik untuk terlibat aktif dalam mengajukan pertanyaan dan membuat kesimpulan sendiri. Hal ini dapat dimaknai bahwa dalam pembelajaran multiliterasi peserta didik diberikan banyak kesempatan untuk mempelajari materi pembelajaran secara mendalam untuk kemudian dijadikan sebagai pengetahuan yang tersimpan dalam jangka waktu lama (Long Term Memory). 
Nurgiyantoro (2016:424) menganggap bahwa multiliterasi dapat juga dimaknai sebagai kemampuan untuk memahami makna, memaknai, mengkritisi, dan mengevaluasi berbagai sumber informasi, serta kemudian mengkomunikasikan kembali sesuai dengan pemaknaannya.

Dari definisi diatas, dapat disimpulkan bahwa multiliterasi merupakan kemampuan untuk memahami makna atau ide dan informasi dengan menggunakan beragam cara yang selanjutnya bertujuan untuk mengkomunikasikan kembali makna yang dimunculkan.

Disamping memahami konsep multiliterasi, perlu dipahami juga mengenai kompetensi multiliterasi. Nurgiyantoro (2016:424) memaknai bahwa kompetensi multiliterasi sedikitnya mencakup 4 aspek, yaitu literasi membaca dan menulis konvensional, digital, visual, dan sikap kritis. Dari pendapat diatas, dapat dipahami bahwa kompetensi multiliterasi bersinergi dengan literasi (membaca dan menulis), digital, visual, dan sikap kritis dan kreatif.

Pembelajaran multiliterasi diharapkan mampu mengembangkan ide-ide tulisan dalam bentuk teks deskriptif Bahasa Inggris dengan menggabungkan teknik kolaborasi dalam proses pembelajaran Bahasa Inggris dikelas. Meskipun tekadang terdapat banyak masalah-masalah yang terjadi disekolah sehingga proses pembelajaran multiliterasi sedikit terhambat seperti kurang tersedianya sarana dan prasarana pembelajaran yang memadai. Masih dengan mudah kita menemui fasilitas pembelajaran bahasa Inggris yang belum memadai di sebagian sekolah, seperti belum tersedianya ruang laboratorium bahasa yang sesuai dengan tuntutan pembelajaran bahasa yang mengedepankan pengembangan berfikir kritis dan kreatif, dan sebaliknya fasilitas disekolah sudah cukup memadai namun karna keterbatasan guru dalam penggunaan fasilitas yang telah di berikan pemerintah sehingga tidak tidak tepat guna, dan masih banyak guru yang mengajar dengan cara yang sangat minim sehingga hasil yang didapat juga sangat minimal. Kondisi diatas menjadikan proses penilaian multiliterasi dinilai menjadi kendala serius bagi peserta didik. Disatu sisi, mereka belum diajarkan dengan pola multiliterasi, disisi lain mereka dihadapkan dengan penilaian yang mengedepankan multiliterasi. Hal ini tentunya berdampak negatif bagi peserta didik. Mereka terkesan belum mampu berkompetisi ketika mereka menyelesaikan pendidikan mereka.

Selanjutnya masalah teknik serta metode mengajar. Masih terdapat sebagian guru yang enggan untuk membuka diri dalam rangka memperkaya pengetahuan mengenai metode pengajaran. Mereka cenderung menganggap bahwa mereka sudah banyak pengalaman mengajar dan merasa sudah cukup mumpuni dalam mengajar. Ketika diutus untuk mengikuti pelatihan mengenai metode pengajaran, mereka enggan untuk mengikuti kegiatan tersebut. Sebagai akibatnya, cara mereka mengajar cenderung bersifat monoton (membosankan). Metode Pembelajaran Kolaborasi diharapkan mampu mengembangkan ide-ide yang cemerlang yang dimiliki peserta didik dengan pembelajaran multiliterasi dalam menulis sebuah teks deskriptif bahasa Inggris.

Tulisan kolaborasi, yang memaksimalkan keterlibatan peserta didik dan keterlibatan dalam praktik pembelajaran bahasa, telah berubah menjadi tujuan bernilai sarat, bertujuan, dan komunikatif. Kolaborasi ini memberi siswa kesempatan untuk berinteraksi dan menantang pengetahuan bahasa mereka di lingkungan belajar yang lebih efektif (Willis, 1996, dikutip dalam Biria \& Jafari, 2013).

Sejalan dengan penjelasan diatas, peserta didik harus terlibat secara aktif sehingga pembelajaran berpusat pada peserta didik. Ketika pembelajaran sudah terpusat pada peserta didik, akan dengan mudah terbentuk kompetensi literasi, kompetensi kolaborasi, kompetensi berfikir kritis dan kreatif serta kompetensi TIK. Hal ini yang diatas sudah dijelaskan menjadi harapan dalam pembelajaran multiliterasi yang bersinergi dengan pembelajaran abad ke-21. 
Meskipun menulis pada umumnya dianggap sebagai aktivitas individu yang dengannya gagasan ditransmisikan dari seorang pengalamatan ke penerima, kolaborasi secara tertulis semakin menarik perhatian dalam pengajaran dan penilaian bahasa (misalnya, DiCamilla \& Anton, 1997). Tulisan kolaboratif, yang memaksimalkan keterlibatan peserta didik dan keterlibatan dalam praktik pembelajaran bahasa, telah berubah menjadi tujuan bernilai sarat, bertujuan, dan komunikatif. Kolaborasi ini memberi siswa kesempatan untuk berinteraksi dan menanthang pengetahuan bahasa mereka di lingkungan belajar yang lebih efektif (Willis, 1996, dikutip dalam Biria \& Jafari, 2013).

Dari penjelasan mengenai definisi dan keutamaan pembelajaran multiliterasi dan teknik kolaborasi serta keterbatasan kemampuan siswa dalam mengembangkan ide serta gagasan yang akan mereka sampaikan dalam sebuah karya tulis sehingga tak jarang mereka menulis dengan tulisan yang sangat jauh dari kata sempurna serta ide-ide yang sangat tidak beretika, makapenulistertarikuntukmengembangkan sebuah makalah yang merupakan sebuah kajian tori tentang Pembelajaran Multiliterasi menulis Teks deskriptif Bahasa Inggris melaui teknik kolaborasiyang mungkin bisa dijadikan sebuah referensi yang tepat bagi guru dan dosen dalam proses pembelajaran yang lebih modern dalam menciptakan peserta didik yang berkharakter dalam menghadapi era disrupsi ini.

\subsection{Masalah}

Masalah yang akanakandibahasmeliputi:

1. Keterbatasan ide serta gagasan yang ingin disampaikan dalam sebuah karya tulis Teks deskriptif Bahasa Inggris;

2. Keterbatasan penguasaan tata bahasalnggris;

3. Keterbatasan dalam kosakata yang akan dituangkan dalam sebuah teks deskriptif;

4. Fasilitas disekolah yang kurang dimanfaatkan dalam mendukung pengembangan ide serta gagasan dalam pembelajaran multiliterasi

\section{TINJAUAN PUSTAKA}

\subsection{Definisi Multiliterasi}

Multiliterasi merupakan kemampuan menggunakan beragam cara untuk menyatakan dan memahami ide dan informasi dengan menggunakan bentuk-bentuk teks konvensional dan inovatif, simbol dan multi media (Abidin, 2015:3).

\subsubsection{Pembelajaran Multiliterasi}

Pembelajaran multiliterasi merupakan pembelajaran yang dimaksudkan untuk mengembangkan kompetensi berbagai sumber literasi baik literasi visual, multimedia, teknologi, kritis, lintas kurikulum, maupun berbagai sumber literasi yang ada di sekitar kehidupan masyarakat (Nurgiyantoro, 2016:424).

Ini bermakna bahwa di dalam pembelajaran multiliterasi, terdapat beberapa hal yang perlu dikedepankan, antara lain: kompetensi pemahaman, berfikir kritis, berkomunikasi, dan berfikir kreatif. Hal ini sangat berperan bagi peserta didik untuk mampu berkompetisi dalam kehidupan nyata di abad ke-21 ini.

Menulis telah ditetapkan sebagai kompetensi inti pendidikan abad ke-21. Dalam standar inti pembelajaran menulis internasional tersurat bahwa pembelajaran menulis mulai dari jenjang pendidikan dasar hingga pendidikan tinggi harus diarahkan pada 
pengembangan peserta didik pada tiga hal, antara lain: a) menulis argumentasi untuk mendukung hasil analisis terhadap topik-topik substantif dengan menggunakan alasan yang rasional dan bukti yang relevan dan mencukupi, b) menulis teks informatif/eksplanatori untuk menguji dan menyampaikan ide-ide dan informasi yang kompleks secara jelas dan akurat, dan c) menulis narasi untuk mengembangkan pengalaman (Abidin, 2015:172).

Beliau lebih lanjut mengemukakan bahwa setidaknya ada empat fokus utama pembelajaran multiliterasi menulis yang dilaksanakan guru disekolah, antara lain: 1) peserta didik mencintai menulis, 2) peserta didik mampu menulis karya yang indah, jelas, dan kreatif, 3) peserta didik mampu menulis dengan mempertimbangkan berbagai konteks, dan 4) peserta didik mampu melaksanakan penelitian baik penelitian jangka pendek ataupun jangka panjang yang hasilnya akan digunakan sebagai sumber ide dalam menulis.

Dengan mempertimbangkan fokus utama pembelajaran multiliterasi menulis diatas, terdapat beberapa konsekuensi yang harus dilakukan guru selama pembelajaran menulis, antara lain: 1) guru hendaknya menguasai berbagai strategi menulis, konsep jenis-jenis tulisan, dan media publikasi bagi wahan tulisan yang dihasilkan peserta didik, 2) guru hendaknya terbiasa menulis agar ia mampu menjadi model menulis bagi para peserta didiknya, 3) guru hendaknya senantiasa melatih seluruh kemampuan peserta didik sejak dari tahapan penangkapan ide sampai tahap penyampaian ide, 4) selama pembelajaran menulis, guru hendaknya senantiasa memberikan bimbingan, arahan, dan motivasi agar peserta didik terpacu untuk menulis, dan 5) pembelajaran menulis hendaknya tidak dibatasi ruang kelas melainkan boleh dilakukan dimana pun agar peserta didik bisa fokus dan senang menulis (Abidin, 2015:177).

\subsubsection{Penilaian Pembelajaran Multiliterasi dalam Kompetensi Menulis Bahasa Inggris}

Terminologi penilaian pembelajaran multiliterasi dalam kompetensi menulis bahasa Inggris memiliki dua dimensi, yakni evaluasi proses pembelajaran dan evaluasi hasil belajar. Penilaian proses pembelajaran merupakan sistem evaluasi yang perlu dilakukan oleh pengajar untuk menentukan kualitas pembelajaran, dalam hal ini proses pembelajaran menulis bahasa Inggris. Kegiatan ini disebut sebagai refleksi proses pembelajaran. Melalui kegiatan ini guru akan menemukan kelebihan dan kekurangan dari proses pembelajaran yang telah dilakukan. Penilaian proses pembelajaran adalah proses untuk menentukan nilai dan manfaat kegiatan pembelajaran melalui kegiatan penilaian dan pengukuran. Pembuatan penilaian pembelajaran mencakup pertimbangan tentang hasil, proses pembelajaran, dan manfaat program. Sedangkan penilaian hasil belajar menekankan pada informasi sejauh mana hasil penilaian yang dicapai oleh peserta didik sesuai dengan tujuan yang telah ditetapkan. Dengan demikian, penilaian hasil belajar menetapkan baik buruknya hasil dari kegiatan pembelajaran (Dimyati dan Mudjiono, 2006:221).

Penilaian pembelajaran multiliterasi dalam keterampilan menulis perlu memperhatikan jenis tulisan (tulisan akademik, tulisan berhubungan dengan pekerjaan, dan tulisan pribadi) dan jenis performansi tulisan (imitatif,intensif, responsif, dan ekstensif) (Brown, 2004:219-220).

Adapun sasaran penilaian meliputi ranah kognitif, afektif, psikomotor. Kognitif berhubungan dengan ingatan atau pengenalan terhadap informasi dan pengetahuan. Afektif berhubungan dengan sikap, penghargaan, perhatian, nilai, perasaan. Psikomotor berhubungan dengan keterampilan motorik, manipulasi benda yang memerlukan kerja saraf dan badan. Pembelajaran multiliterasi menulis berbahasa Inggris dapat di dinilai menggunakan ketiga ranah tesebut menggunakan Rubrik 
Penilaian Proses, Rubrik Penilaian Produk, dan Rubrik Penilaian Karakter (Abidin, 2015:338-342).

\subsection{Definisi Menulis}

Dari empat keterampilan dalam bahasa Inggris, meulisan dianggap sebagai keterampilan yang paling kompleks dan sulit untuk dikuasai. Kesulitan ini, menurut Richards dan Renandya (2002, hal 303), "terletak tidak hanya dalam menghasilkan dan mengorganisir gagasan tapi juga menerjemahkan gagasan ini menjadi teks yang mudah dibaca."

\subsubsection{Keterampilan Komunikatif dalam Menulis}

Menurut lyer (2013:2), "keterampilan komunikasi adalah keterampilan yang memungkinkan seseorang menyampaikan informasi sehingga diterima dan dipahami". Keterampilan berkomunikasi secara tertulis ditunjukkan dengan cara seseorang dapat mengekspresikan pikirannya dengan jelas. Penelitian ini difokuskan pada empat keterampilan komunikatif secara tertulis, yaitu, pemikiran kritis, kreativitas, suara dan komentar.

\subsubsection{Kemampuan Menulis Komunikatif}

\section{a. Kreativitas}

Sejauh menyangkut kreativitas, bentuk kolaborasi online ini dapat digunakan untuk menciptakan hubungan yang kuat antara siswa, kolaborasi dan memberi kesempatan kepada siswa untuk menampilkan kreativitas mereka (Johnson, 2010). lyer (2013:21), mengklaim bahwa "Saya melihat kolaborasi sebagai langkah awal alami proses kreatif. Selain itu, lyer (2013:21) tidak semua proyek dapat mengakomodasi, fase eksplorasi dan pertukaran kreatif. Kolaborasi itu bagus untuk kreativitas, tapi pilihan cerdas tentang karakteristik pasangannya harus dilakukan.

\section{b. Berfikir Kritis}

Mengikuti kreativitas, berfikir kritis adalah keterampilan komunikatif penting lainnya dalam menulis. "Pemikiran kritis adalah bentuk pemikiran realistis dan perseptif yang berfokus pada penentuan apa yang harus dilakukan dan bagaimana melakukannya" lyer (2013:22). Menurut Pohl (2000), pemikiran kritis telah dikategorikan dalam menciptakan, mengevaluasi, menganalisis, menerapkan, memahami dan mengingat, di mana menciptakan, mengevaluasi, dan menganalisis adalah keterampilan berpikir tingkat tinggi. Pemikiran kritis, seperti itu, telah didefinisikan sebagai proses menganalisis dan mengevaluasi pemikiran dengan tujuan untuk mencoba memperbaikinya.

Pohl (2000) percaya bahwa pemikiran kritis dapat dilihat sebagai memiliki dua komponen: 1) seperangkat keterampilan menghasilkan dan mengolah informasi, dan 2) kebiasaan, berdasarkan komitmen intelektual, menggunakan keterampilan tersebut untuk membimbing perilaku. Proses penulisan ini dengan saksama mengarah pada pengembangan kemampuan berpikir kritis. lyer (2013:23)

\subsection{Definisi Kolaborasi}

Roschelle dan Teasley (1995), kolaborasi adalah aktivitas sinkron dan terkoordinasi yang dihasilkan dari usaha terus-menerus untuk membangun dan mempertahankan konsepsi bersama tentang suatu masalah. Telah dikatakan bahwa siswa dapat belajar dengan baik dalam konteks pembelajaran kolaboratif yang lebih berpusat pada peserta didik dibandingkan dengan pengaturan pembelajaran 
individualistik dan kompetitif, peserta didik berpartisipasi aktif dalam konteks pembelajaran kolaboratif dan membangun pengetahuan linguistik mereka melalui interaksi dengan peserta didik lainnya. Dengan demikian, Boud (2001) telah memperkenalkan istilah peer learning sebagai cara efektif untuk pasangan belajar dari dan satu sama lain.

\subsection{Langkah-Langkah Pembelajaran Kolaborasi}

Berikut ini langkah-langkah pembelajaran kolaborasi. https://kurniawanbudi04.wordpress.com/2013/05/27/collaborative-learning/

1. Para siswa dalam kelompok menetapkan tujuan belajar dan membagi tugas sendiri-sendiri.

2. Semua siswa dalam kelompok membaca, berdiskusi, dan menulis.

3. Kelompok kolaboratif bekerja secara bersinergi mengidentifikasi, mendemontrasikan, meneliti, menganalisis, dan memformulasikan jawabanjawaban tugas atau masalah dalam LKS atau masalah yang ditemukan sendiri.

4. Setelah kelompok kolaboratif menyepakati hasil pemecahan masalah, masingmasing siswa menulis laporan sendiri-sendiri secara lengkap.

5. Guru menunjuk salah satu kelompok secara acak (selanjutnya diupayakan agar semua kelompok dapat giliran ke depan) untuk melakukan presentasi hasil diskusi kelompok kolaboratifnya di depan kelas, siswa pada kelompok lain mengamati, mencermati, membandingkan hasil presentasi tersebut, dan menanggapi. Kegiatan ini dilakukan selama lebih kurang 20-30 menit.

6. Masing-masing siswa dalam kelompok kolaboratif melakukan elaborasi, inferensi, dan revisi (bila diperlukan) terhadap laporan yang akan dikumpulan.

7. Laporan masing-masing siswa terhadap tugas-tugas yang telah dikumpulkan, disusun perkelompok kolaboratif.

8. Laporan siswa dikoreksi, dikomentari, dinilai, dikembalikan pada pertemuan berikutnya, dan didiskusikan.

\section{PEMBAHASAN}

\section{1 Keterbatasan ide serta gagasan yang ingin disampaikan dalam menulis teks deskriptif Bahasa Inggris}

Ide merupakan hal yang sangat mendasar yang kita miliki dalam menulis sebuah teks, namun tak jarang kita ataupun peserta didik akan mengalami dimana kita tidak memiliki ide ataupun gagasan dalam meuliskan sebuah karya tulis. Terkadang untuk mencari sebuah inspirasi dalam sebuah tulisan kita menghabiskan waktu berjam-jam hanya untuk merenung dan menggali potensi yang ada di kepala kita, bahkan tak jarang kita pergi kesuatu tempat yang mungkin bisa kita jadikan sebuah inspirasi dalam tulisan kita, bahkan kita cenderung memilih waktu dan tempat yang sangat tepat untuk menuangkan ide atau pun gagasan dalam sebuah karya tulis. Begitupun bagi peserta didik kita yang memiliki keterbatasan ide dan gagasan untuk menjadi dasar dalam sebuah tulisan, inilah peran guru dan dosen untuk menggali ide dan potensi yang ada dalam diri mereka yang mungkin akan menjadi inspirasi dalam tulisan mereka. Guru dan dosen harus memiliki teknik serta trik yang mampu membangkitkan potensi yang ada dalam diri peserta didik kita, ada beberapa trik yang bisa kita gunakan; (1) bisa dalam bentuk interview atau tanya jawab yang mengarah kepada apa dan topik apa yang akan dikembangkan menjadi sebuah tulisan. (2) dengan menggunakan pembelajaran multiliterasi pemanfaatan teknologi melalui internet dan gambar yang nantinya akan menggali ide yang ada dalam diri pribadi 
siswa atau peserta didik agar muncul dengan sendirinya dengan bantuan guru atau pun dosen. (3) Teknik kolaborasi yang mampu menggabungkan ide-ide yang dimiliki oleh peserta didik yang lain sehingga ide baru akan muncul dengan sendirinya.

\subsection{Keterbatasan penguasaan tata bahasalnggris}

Dalam menulis teks Bahsa Inggris tata bahasa jiga hal yang sangat penting, karena pemahaman sebuah bacaan bahasa inggris sangat dipengaruhi oleh tata bahasa Inggris yang baik dan benar. Terkadang siswa kita memiliki keterbatasan dalam penyusunan kata dan tata bahasa Inggris, inilah peran guru atau dosen dalam membimbing siswa dalam penyusunan tata bahasa yang baik, dengan penyesuaikan konsep-konsep struktur bahasa yang digunakan dalam sebuah teks Bahasa Inggris. Melatih siswa dalam berkomunikasi dan merubahnya dalam bentu tulisan yang sesuai dengan tata bahasa dan struktur kalimat dalam bahasa Inggris

\subsection{Keterbatasan dalam kosakata yang akan dituangkan dalam sebuah teks deskriptif}

Pemilihan kosakata adalah hal yang sangat penting dalam sebuah tulisan. Terkadang siswa memiliki kesulitan dalam penggunaan kosakata dikarenakan terbatasnya kosakata yang mereka miliki hal ini bisa teratasi dengan bantuan kamus dalam bentuk buku dan kamus elektronik. Dengan penerapan pembelajaran multiliterasi diharapkan siswa mampu mengatasinya dengan menggunakan kamus elektronik yang terdapat dalam sebuah aplikasi internet yang menjadi fasilitas. Bagi sekolah yang belum memiliki fasilitas yang memadai siswa dapat menggunakan bantuan kamus dalam bentuk buku yang bisa digunakan tentunya juga dengan bantuan dan bimbingan dari guru bahasa Inggris. Peran guru dalam menambah kosakata siswa dalam pembelajaran Bahasa Inggris sangatlah penting. Guru bisa menggunakan metode hafal 50 kata dalam 15 menit dapat diterapkan dalam menggali daya ingat siswa. Dengan menggunakan metode ini siswa mampu memiliki perbendaharaan kata yang banyak.

\subsection{Fasilitas disekolah yang kurang dimanfaatkan dalam mendukung pengembangan ide serta gagasan dalam pembelajaran multiliterasi}

Fasilitas yang kurang memadai adalah salah satu fakor tidak tercapainya pembelajaran multiliterasi,karena pembelajaran multilitersasi adalah sebuah pembelajaran mengembangkan kompetensi berbagai sumber literasi baik literasi visual, multimedia, teknologi, kritis, lintas kurikulum, maupun berbagai sumber literasi yang ada di sekitar kehidupan masyarakat. Salah satunya adalah multimedia yang bisa digunakan dalam pembelajaran multiliterasi. Multimedia ini bisa disebut sebagai fasilitas pendukung yang ada disekolah seperti, jaringan internet, laboratorium bahasa Inggris, ruang kelas khusus drama dan lain-lain. Namun demikian fasilitas yang kurang memadai tersebut bisa kita atasi dengan menggunakan atau mengkreasikan ruangan sebaik mungkin dengan menata ruangan sesuai dengan tema yang akan kita bahas pada pertemuan itu. Misalnya kelas drama Bahasa Inggris dengan tema Hospital, siswa kita bisa mempersiapkan perlengkapan yang sering kita lihat dirumah sakit dan lain-lain, misalnya; pakaian dokter yang akan dipakai oleh seorang yang berperan dokter dan lain lain. Dengan demikian siswa kita akan lebih termotivasi dalam menuliskan sebuah teks Deskriptif dari sebuah cerita drama. Jadi pemahaman multiliterasi disini tidak hanya menceritakan hal-hal yang berhubungan dengan multimedia namun kreatifitas guru dan siswa juga sangat diutamakan untuk merangsang kemampuan berfikir kritis siswa kita. 


\section{SIMPULAN}

Dari penjelasan diatas dapat disimpulkan bahwa pembelajaran multiliterasi bisa kita gunakan sebagai salah satu pembelajaran bahasa Inggris yang lebih modern dan sangat cocok dan sesuai dengan perkembangan zaman saat ini, tentunya dengan menggunakan teknik kolaborasi yang akan menjadikan suasana kelas menjadi lebih aktif dan kreatif. Pembelajaran multilitersasi ini juga mampu mengembangkan cara berfikrir kritis dari peserta didik kita dalam proses pembelajaran tentunya dengan bantuan dan dukungan dari guru kelas yang mampu menggali potensi dan membentuk kharakter peserta didik menjadi lebih baik lagi.

Berdasarkan penjelasan diatas, saran yang bisa disampaikan adalah: (1) Pembelajaran multiliterasi dengan menggunakan teknik kolaborasi bisa dijadikan salah satu alternatif dalam pembelajaran Bahasa Inggris; (2) Fasilitas yang sangat memadai dan merata disetiap sekolah sangat dibutuhkan dan diperlukan bagi pembelajaran abad 21 ini, sehingga guru dan peserta didik merasakan pendidikan dan fasilitas sekolah dengan merata sehingga proses pembelajaran disekolah menjadi lebih baik lagi; (3) Guru lebih kreatif dalam menggali potensi yang ada dalam diri siswa sehingga proses pembelajaran dapat tercapai dengan baik

\section{DAFTAR PUSTAKA}

Abidin, Yunus. (2014). Desain Sistem Pembelajaran dalam Konteks Kurikulum 2013. Bandung: PT Refika Aditama.

Biria \&S. Jafari (2013). The impact of collaborative writing on the writing fluency of Iranian EFL learners. Journal of Language Teaching and Research, 4 (1), 164175

Brown, Douglas. H. (2004). Language Assessment, Principles and Classroom Practices. San Fransisco: Longman.

Boud, D. (2001). Introduction: Making the move to peer learning. In R. Biria\&S. Jafari

DiCamilla, F. J., \&Anton, M. (1997). Repetition in the collaborative discourse of L2 learners:

Dimyati dan Mudjiono. 2006. Belajar dan Pembelajaran. Jakarta: PT. Rineka Cipta.

lyer, P., (2013). Effects of collaborative blogging on communicative skills in writing of Thai

Nurgiyantoro, Burhan. 2016 (Ed. Ke-2). Penilaian Pembelajaran Bahasa Berbasis Kompetensi. Yogyakarta: BPFE.

Pohl, K. (2000). Learning to Think, Thinking to Learn , p.8. Retrieved from http:// www .

Richard, J. S., Renandya et. al (2002). Reading to Learn in the Content Areas. Australia: Wadsworth Cengage Learning.

Roschelle, J. \& Teasley, S. D. (1995). The construction of shared knowledge in collaborative problem solving. In R. Biria \&S. Jafari (2013). The impact of collaborative writing on the writing fluency of Iranian EFL learners. Journal of Language Teaching and Research, 4 (1), 164-175.

Willis, J. (1996). A framework for task-based learning. London: Longman.

https://kurniawanbudi04.wordpress.com/2013/05/27/collaborative-learning/ Diakses tanggal 20April 2017. Pkl. 13.00 